\title{
Neuroendocrine Carcinoma of the Breast - Preliminary Analysis of Treatment Results of 30 Patients
}

\author{
Barbara Kozakiewicz ${ }^{* 1,2}$, Małgorzata Czetwertyńska ${ }^{1}$, Małgorzata Chądzyńska ${ }^{3}$ \\ ${ }^{I}$ Maria Skłodowska-Curie Institute of Oncology Warsaw, Poland \\ ${ }^{2}$ Medical University of Warsaw Faculty of Health Sciences in Warsaw, Poland \\ ${ }^{3}$ Institute of Psychiatry and Neurology, Warsaw, Poland
}

\begin{abstract}
*Corresponding Author: Barbara Kozakiewicz, Maria Skłodowska-Curie Institute of Oncology Warsaw, Medical University of Warsaw Faculty of Health Sciences in Warsaw, Poland, Email: wum@wp.eu
\end{abstract}

\section{Abstract}

Aims: In the following article we present to neuroendocrine carcinoma of the breast-preliminary analysis of treatment results as well as a review of literature.

Materials and Methods: In the period 1995-2009, the Institute of Oncology in Warsaw treated 30 female patients with (NET) neuroendocrine carcinoma of the breast, aged 40 to 88, with the average age of 63 $(S D=12.67)$. The follow up period ranged from 7 months to 16 years. $(S D=4.25$ years). In 20 patients, a minimum follow up period was 36 months. The probability of survival in the test groups was determined using the Kaplan-Meier method and compared using the log-rank test. The trends presented are the results of analyses carried out on a small test sample.

Results: Chromogranin A was found in $80 \%$ and synaptophysin in $97 \%$ of patients in at least $50 \%$ of tumour cells - according to the WHO report from 2003 defining the eligibility criteria of neuroendocrine tumours. Most of the patients had ERC and PRC receptors - respectively 73\% and 57\%, HER-2 receptor was present in only $10 \%$ of the patients. Two patients after primary treatment had developed other tumours: of the cervix and the colon. In 9 patients, disease also occurred among relatives. All patients were treated according to the NCCN guidelines for breast cancer. In the study group, the probability of 5-year survival in the disease-free period was $60 \%$. The probability of 5-year survival was $78 \%$.

Conclusions: The analysis is carried out on a group of 30 patients and the preliminary observations obtained may contribute to the knowledge of the course and dynamics of NET breast cancer. Lack of randomised trials does not allow for unambiguous assessment of prognosis and selection of the best treatment for NET.

Keywords: Chromogranin, NET, Neuroendocrine carcinoma of the breast, Synaptophysin

\section{INTRODUCTION}

In Poland, there are about 10,000 incidences of breast cancer per year, which accounts for $20 \%$ of all diagnosed malignancies. Neuroendocrine tumours represent less than $5 \%$ of all breast cancers but their occurrence has been slowly yet constantly growing. Among the sufferers are women, men with this form of cancer are a casuistry ${ }^{[1,2]}$.

Between 2.5 and 5 persons per 100,000 become ill with neuroendocrine carcinoma of the breast per year, and in autopsy studies, occurrence is found 2 - 5 times more often. Approximately $70 \%$ of neuroendocrine tumours are tumours of the gastrointestinal tract and pancreatic tumours
${ }^{[3]}$. In recent years, there is an observed increase in the incidence of neuroendocrine tumours which inevitably has to do with the improvement of detection but also indicates a greater effectiveness of diagnostic methods.

Only breast cancers occurring rarely, which include apocrine carcinoma, secretory carcinoma, endocrine carcinoma as well as fatty tissue carcinoma and glycogen carcinoma did not receive the WHO recommendation about the doctrine of diagnostic and therapeutic procedures. In the most recent WHO classification from 2003, a new rare form of primary cancer was isolated, called neuroendocrine carcinoma of the breast, defined as $\mathrm{Ne}$; neuroendocrine cancer $(\mathrm{NET})^{[4,5]}$. NET 
diagnosis criteria based on the 2003 report require, in addition to microscopic assessment, immunohisto chemical determination of biogenic amines, peptides, polypeptides, their precursors and metabolites, which are produced by tumour cells. In the diagnosis of neuroendocrine carcinoma, the expression of concentrations in serum of chromogranin A (CgA), synaptophysin, and NES-neuron specific enolase are most commonly used. The said WHO report defines as NET tumours those, which are characterised by the presence in at least $50 \%$ of the cells of at least one of the markers: $\mathrm{CgA}$, NES and/or synaptophysin. Chromogranin A is the most specific marker used to diagnose neuroendocrine carcinoma of the breast as well as to differentiate the primary breast tumour from metastatic lesions ${ }^{[6-8]}$.

Neuroendocrine carcinoma of the breast is very rare. The first reports of the existence of neuroendocrine cells in the tissues of the breast were described by Vogler in 1947. The first incidence of this type of cancer in the breast was described by Cubilla and Woodruff in 1977. So far, the literature describes less than 40 cases of this rare cancer. WHO distinguishes 4 subtypes of primary neuroendocrine breast tumours: small cell carcinoma (SCC), multicellular carcinoma, solid neuroendocrine carcinoma and atypical carcinoid ${ }^{[5,8,9]}$.

Neuroendocrine carcinoma of the cancer is a tumour that exhibits morphological characteristics similar to neuroendocrine tumours both of the gastrointestinal tract and lungs.

In morphological terms, neuroendocrine carcinoma forms cytoplasmic cells with a small nucleus within which no distinct nucleolus has been found. Cancer primarily develops in the submucosa. Most of these tumours are diagnosed in people over 60 years of age ${ }^{[10,11]}$.

Neuroendocrine tumours are a heterogeneous group of neoplasms which are distinct clinicopathological entities. This heterogeneity is manifested in diverse biology and clinical course, the presence or absence of hormonal activity, the difficulty of diagnosis as well as determining the susceptibility to treatment and determining the prognosis ${ }^{[12,13]}$. Neuroendocrine tumours in most cases are highly differentiated and hormonally active. They originate from endocrine gland cells, i.e. the pituitary gland, parathyroid glands, adrenal medulla and from neurosecretory cells resulting from neoplastic transformation, called Kulczycki's cells. These tumours, depending on their hormonal activity, may cause more or less severe clinical symptoms. They can also develop without symptoms, which may be associated with the tumour producing biologically-inactive compounds and with the secretion of antagonistically acting substances relative to each other ${ }^{[14]}$.

\section{MATERIALS AND METHODS}

In the period 1995-2009, the Institute of Oncology in Warsaw treated 30 female patients with (NET) neuroendocrine carcinoma of the breast, aged 40 to 88 , with the average age of 63 $(\mathrm{SD}=12.67)$.

The follow up period ranged from 7 months to 16 years. ( $\mathrm{SD}=4.25$ years). In 20 patients, a minimum follow up period was 36 months. The characteristic of clinical features among the patients studied is presented in Table 1. Histopathological diagnosis was established according to the classification of neuroendocrine tumours included in the 2003 WHO report. Chromogranin A was found in $80 \%$ (24/30) and synaptophysin in $97 \%$ (29/30) of patients. Other markers - CK7, CK20, GCDFP, NSE were found only in 8 patients. None of the patients had previously diagnosed cancer and the diagnostic procedure did not exceed 2 months.

Tumours in the breasts were diagnosed on the basis of imaging mammography and/or ultrasound. Breast tumour size ranged from 0.5 to $5 \mathrm{~cm}$. In each case, a biopsy (BAC) of the lesions was performed. Neuroendocrine cancer was diagnosed after surgery to remove the tumour in 27 cases, and in 3 patients who were not operated on due to the spread of the disease, the diagnosis was established after a biopsy of breast tumour and changes in the axillary lymph nodes. In 1 patient synchronous neuroendocrine cancer of both breasts was found. All patients were treated in accordance with the clinical severity of the disease according to the guidelines of the NCCN (National Comprehensive Cancer Network) for breast cancer.

The Statistica 10 package was used for data analysis. The probability of survival in the test groups was determined using the Kaplan-Meier method and compared using the log-rank test. The trends presented are the results of analyses carried out on a small test sample. Therefore, the results with a value of $p<0.1$ were considered statistically significant [Table1.] 
Table1. Clinical features of neuroendocrine carcinoma of the breast diagnosed in 30 patients

\begin{tabular}{|c|c|c|c|}
\hline \multicolumn{2}{|c|}{ Cancer tissue features } & \multirow{2}{*}{$\begin{array}{c}\begin{array}{c}\text { Study } \\
\text { group } \\
\text { size } N\end{array} \\
13\end{array}$} & \multirow{2}{*}{$\%$} \\
\hline $\mathbf{T}$ & $\mathrm{T}_{1}$ & & \\
\hline & $\mathrm{T}_{2}$ & 11 & 37 \\
\hline & $\mathrm{T}_{3}$ & 3 & 10 \\
\hline & $\mathrm{T}_{4}$ & 3 & 10 \\
\hline $\mathbf{N}$ & $\mathrm{N}_{1}$ & 19 & 62 \\
\hline $\mathbf{M}$ & $\mathrm{M}_{1}$ & 2 & 6 \\
\hline Histopathology: & $\begin{array}{c}\text { Neuroendocrine } \\
\text { carcinoma }\end{array}$ & 15 & 48 \\
\hline \multirow{2}{*}{$\begin{array}{c}\text { Neuroendocrine } \\
\text { with the } \\
\text { component: }\end{array}$} & $\begin{array}{c}\text { Carcinoma } \\
\text { ductale }\end{array}$ & 10 & 33 \\
\hline & $\begin{array}{c}\text { Carcinoma } \\
\text { lobulare }\end{array}$ & 2 & 7 \\
\hline Other forms: & $\begin{array}{l}\text { Medullare, } \\
\text { mixtum, } \\
\text { papillare }\end{array}$ & 3 & 10 \\
\hline \multirow[t]{3}{*}{$\mathbf{G}$} & $\mathrm{G}_{1}$ & 3 & 1 \\
\hline & $\mathrm{G}_{2}$ & 16 & 53 \\
\hline & $\mathrm{G}_{3}$ & 11 & 37 \\
\hline $\mathbf{N}$ & patients & \multicolumn{2}{|c|}{$100 \% \%^{30}$} \\
\hline
\end{tabular}

$T$-tumour, $N$ - noduli, $M$-metastases, $G$ - degree of malignancy, $N$-study group

Estrogen and progesterone receptors were observed in most of the patients, respectively $73 \%$ and $57 \%$. HER-2 receptor was present in $10 \%(3 / 30)$ of the patients. Among all 30 patients, 7 (23\%) were triple receptor-negative.

The second occurrence of cancer was found in 2 patients during the year of finishing treatment. It was squamous cell cancer of the cervix and adenocarcinoma of the colon, both without the neuroendocrine component (Table 2).

Incidence of cancer among relatives occurred in 9 out of $30(30 \%)$ of patients. Diseased relatives had 1st, 2nd and 3rd degree of kinship. Neuroendocrine tumour was not diagnosed in any of them (Table 2). In this group, HER-2 receptor was observed in 2 patients (+), and 3 patients were among the triple receptor-negative $(-)$.

Table2. Degree of kinship and development of malignancy with an assessment of the fate of the studied patient with NET

\begin{tabular}{|c|c|c|c|}
\hline Patient & $\begin{array}{c}\text { Relative } \\
\text { with the } \\
\text { disease }\end{array}$ & $\begin{array}{c}\text { Location } \\
\text { of cancer }\end{array}$ & $\begin{array}{c}\text { Follow } \\
\text { up }\end{array}$ \\
\hline 1.PC & Father & Anus & $\begin{array}{c}\text { Alive } \\
\text { after 6 } \\
\text { years }\end{array}$ \\
\hline 2. SE & Brother & Pancreas & Death \\
\hline
\end{tabular}

\begin{tabular}{|c|c|c|c|}
\hline & & & $\begin{array}{c}\text { after } 1 \\
\text { year }\end{array}$ \\
\hline 3. SJ & $\begin{array}{l}\text { Mother, two } \\
\text { aunts }\end{array}$ & Breast & $\begin{array}{c}\text { Alive } \\
\text { with neo } \\
\text { for } 6 \\
\text { years }\end{array}$ \\
\hline $4 . \mathrm{KH}$ & $\begin{array}{c}\text { Mother, aunt, } \\
\text { niece }\end{array}$ & $\begin{array}{c}\text { Breast, } \\
\text { breast, brain }\end{array}$ & $\begin{array}{l}\text { Death in } \\
3 \text { years }\end{array}$ \\
\hline $5 . Z Z^{*}$ & Father & Prostate & $\begin{array}{c}\text { Was } \\
\text { alive for } \\
3 \text { years }\end{array}$ \\
\hline 6. GJ & $\begin{array}{l}\text { Grandmother, } \\
\text { sister }\end{array}$ & $\begin{array}{c}\text { Ovarian, } \\
\text { breast }\end{array}$ & $\begin{array}{l}\text { Alive } \\
\text { for } 3 \\
\text { years }\end{array}$ \\
\hline 7.MD & $\begin{array}{c}\text { Father, sister, } \\
\text { aunt }\end{array}$ & $\begin{array}{l}\text { Stomach, } \\
\text { lungs, } \\
\text { endometrial }\end{array}$ & $\begin{array}{c}\text { Alive } \\
\text { with neo } \\
\text { for } 3 \\
\text { years }\end{array}$ \\
\hline $\begin{array}{c}8 . \\
\mathrm{BZ} * *\end{array}$ & Mother, sister & $\begin{array}{c}\text { Thyroid, } \\
\text { anus }\end{array}$ & $\begin{array}{l}\text { Death in } \\
10 \\
\text { months }\end{array}$ \\
\hline 9. JZ & Sister & Sigmoid & $\begin{array}{c}\text { Alive } 1 \\
\text { year }\end{array}$ \\
\hline
\end{tabular}

These patients suffered from a 2nd tumour: *cervical cancer and colon cancer**

\section{RESUltS}

Group of 30 patients was observed from 7 months to 16 years ( $\mathrm{SD}=4.25$ years). Recurrence of the disease was diagnosed in 2 patients and distant metastasis in 12 patients. In the course of observation $5(19 \%)$ patients died from cancer and 2 for other reasons. Two patients suffered from a second tumour. In 1 patient, bilateral breast neuroendocrine cancer was diagnosed with positive ERC and PRC receptors and negative HER-2 receptor, and $\mathrm{CgA}$ markers present on both sides, and also synaptophysin on one side. This patient died due to the spread in the third year of follow up.

A detailed analysis was conducted of the survival of 20 patients, who were in follow up for at least 36 months with the recorded date of death, treatment failure in the form of metastasis or recurrence of the disease and second cancer. Due to the small size of the subgroups defined by level variables controlled, it was difficult to compare them. Those variables were assessed, which could influence the outcome of cancer treatment, i.e. incidence of cancer among relatives, tumour size, histological degree of malignancy, the presence of neuroendocrine markers chromogranin A and synaptophysin, steroid receptors ERC, PRC and HER-2 receptor (Table 3). The effect of the occurrence of chromogranin on survival was observed (chiquare $=5.477 ; \mathrm{pv}=0.034$ ). The occurrence of chromogranin was associated with a higher 
probability of survival. This is confirmed by the observation of the occurrence of two substances - chromogranin and synaptophysin.

Table3. Assessment of survival among 20 patients observed for 36 months depending on clinical and microscopic characteristics of cancer.

\begin{tabular}{|c|c|c|c|c|c|c|}
\hline & \multicolumn{2}{|c|}{ Alive } & \multicolumn{2}{|c|}{ Death } & \multirow[b]{2}{*}{$\begin{array}{c}\text { chi- } \\
\text { square }\end{array}$} & \multirow[b]{2}{*}{$\mathbf{p}_{\mathbf{v}}$} \\
\hline $\begin{array}{c}\text { Controlled } \\
\text { variables }\end{array}$ & $\mathbf{n}$ & $\%$ & $\mathbf{n}$ & $\%$ & & \\
\hline \multicolumn{7}{|l|}{$\begin{array}{l}\text { Cancer in the } \\
\text { family }\end{array}$} \\
\hline Occurred & 5 & $\begin{array}{l}18 . \\
5 \%\end{array}$ & 3 & $\begin{array}{l}11 . \\
1 \%\end{array}$ & 0.793 & $\begin{array}{c}0.33 \\
2\end{array}$ \\
\hline Did not occur & $\begin{array}{l}1 \\
5\end{array}$ & $\begin{array}{l}55 . \\
6 \%\end{array}$ & 4 & $\begin{array}{l}14 . \\
8 \%\end{array}$ & & \\
\hline \multicolumn{7}{|l|}{ Tumour diameter } \\
\hline Up to $2 \mathrm{~cm}$ & 7 & $\begin{array}{l}25 . \\
9 \%\end{array}$ & 1 & $\begin{array}{c}3.7 \\
\%\end{array}$ & & \\
\hline $2-5 \mathrm{~cm}$ & 9 & $\begin{array}{l}33 . \\
3 \%\end{array}$ & 3 & $\begin{array}{l}11 . \\
1 \%\end{array}$ & 1.801 & $\begin{array}{c}0.40 \\
6\end{array}$ \\
\hline Above $5 \mathrm{~cm}$ & 4 & $\begin{array}{l}14 . \\
8 \%\end{array}$ & 3 & $\begin{array}{l}11 . \\
1 \%\end{array}$ & & \\
\hline \multicolumn{7}{|l|}{ Histopathology } \\
\hline $\begin{array}{c}\text { with the } \\
\text { component: - } \\
\text { Ductale }\end{array}$ & 8 & $\begin{array}{l}29 . \\
6 \% \\
\end{array}$ & 2 & $\begin{array}{c}7.4 \\
\% \\
\end{array}$ & & \\
\hline Lobulare & 2 & $\begin{array}{c}7.4 \\
\%\end{array}$ & 0 & $\begin{array}{c}0.0 \\
\%\end{array}$ & 1.311 & $\begin{array}{c}0.51 \\
9\end{array}$ \\
\hline Neuroendocrine & $\begin{array}{l}1 \\
0\end{array}$ & $\begin{array}{l}37 . \\
0 \%\end{array}$ & 5 & $\begin{array}{l}18 . \\
5 \%\end{array}$ & & \\
\hline $\mathrm{G}_{1}$ & 1 & $\begin{array}{c}3.7 \\
\% \\
\end{array}$ & 1 & $\begin{array}{c}3.7 \\
\%\end{array}$ & & \\
\hline $\mathrm{G}_{2}$ & $\begin{array}{l}1 \\
1 \\
\end{array}$ & $\begin{array}{l}40 . \\
7 \% \\
\end{array}$ & 3 & $\begin{array}{l}11 . \\
1 \%\end{array}$ & 0.761 & $\begin{array}{c}0.68 \\
3 \\
\end{array}$ \\
\hline $\mathrm{G}_{3}$ & 8 & $\begin{array}{l}29 . \\
6 \%\end{array}$ & 3 & $\begin{array}{l}11 . \\
1 \%\end{array}$ & & \\
\hline \multicolumn{7}{|l|}{ Chromogranin A } \\
\hline None & 2 & $\begin{array}{l}7.4 \\
\%\end{array}$ & 3 & $\begin{array}{l}11 . \\
1 \%\end{array}$ & & \\
\hline+ & $\begin{array}{l}1 \\
1 \\
\end{array}$ & $\begin{array}{l}40 . \\
7 \%\end{array}$ & 4 & $\begin{array}{l}14 . \\
8 \%\end{array}$ & 5.477 & $\begin{array}{c}0.03 \\
4 *\end{array}$ \\
\hline++ & 7 & $\begin{array}{l}25 . \\
9 \%\end{array}$ & 0 & $\begin{array}{c}0.0 \\
\%\end{array}$ & & \\
\hline \multicolumn{7}{|l|}{ Synaptophysin } \\
\hline- & 1 & $\begin{array}{l}3.7 \\
\%\end{array}$ & 0 & $\begin{array}{c}0.0 \\
\%\end{array}$ & & \\
\hline+ & $\begin{array}{l}1 \\
2\end{array}$ & $\begin{array}{l}44 . \\
4 \%\end{array}$ & 3 & $\begin{array}{l}11 \% \\
1 \%\end{array}$ & 1.248 & $\begin{array}{c}0.53 \\
6\end{array}$ \\
\hline++ & 7 & $\begin{array}{l}25 . \\
9 \%\end{array}$ & 4 & $\begin{array}{l}14 . \\
8 \%\end{array}$ & & \\
\hline \multicolumn{7}{|l|}{ ERC } \\
\hline Up to 10 & 5 & $\begin{array}{l}18 . \\
5 \%\end{array}$ & 2 & $\begin{array}{l}7.4 \\
\%\end{array}$ & 0.034 & $\begin{array}{c}0.60 \\
7\end{array}$ \\
\hline Above 10 & $\begin{array}{l}1 \\
5\end{array}$ & $\begin{array}{l}55 . \\
6 \%\end{array}$ & 5 & $\begin{array}{l}18 . \\
5 \%\end{array}$ & & \\
\hline PRc & & & & & & \\
\hline Up to 10 & $\begin{array}{l}1 \\
2\end{array}$ & $\begin{array}{l}44 . \\
4 \%\end{array}$ & 3 & $\begin{array}{l}11 \% \\
1 \%\end{array}$ & 0.617 & $\begin{array}{c}0.36 \\
4\end{array}$ \\
\hline
\end{tabular}

\begin{tabular}{|c|c|c|c|c|c|c|}
\hline & & 29. & 14. & & \\
\hline Above 10 & 8 & $6 \%$ & 4 & $8 \%$ & & \\
\hline HER2 & & & & & & \\
\hline & 1 & 70. & 18. & & 0.14 \\
None & 9 & $4 \%$ & 5 & $5 \%$ & 3.883 & 3 \\
\hline & & 3.7 & 7.4 & & \\
\hline Present & 1 & $\%$ & 2 & $\%$ & & \\
\hline
\end{tabular}

* p-value chi-square statistics $(p<0,05)$

In all patients, the presence of neuroendocrine markers chromogranin A or synaptophysin or both of them together was found in the cancer tissue. Among the patients who had only one marker, $4(57 \%)$ died, while $3(43 \%)$ are alive. And among patients in whom both markers were present, $13(65 \%)$ are alive and cancer-free and $4(20 \%)$ are alive with cancer, while $3(15 \%)$ have died. The presence of both substances is associated with a higher rate of survival.

The survivals of the entire group of 30 patients depending on the characteristics of cancer were compared (Table 4).

Table4. Assessment of the probability of survival of patients in follow up between 7 months and 16 years depending on the clinical and microscopic features of cancer

\begin{tabular}{|c|c|c|c|c|c|}
\hline Feature & $\begin{array}{l}\text { Varia } \\
\text { nt }\end{array}$ & $\begin{array}{l}\text { Probabil } \\
\text { ity of } \\
\text { survival } \\
\text { for } 60 \\
\text { months }\end{array}$ & $\mathbf{n}$ & $\begin{array}{l}\text { Value } \\
\text { of log } \\
\text { rank } \\
\text { statisti } \\
\text { cs }\end{array}$ & $\begin{array}{l}\left(\mathbf{p}_{\mathrm{v}}\right) \\
*\end{array}$ \\
\hline \multirow[t]{3}{*}{$\begin{array}{l}\text { Tumour } \\
\text { size }\end{array}$} & $\begin{array}{l}<=2 \\
\mathrm{~cm}\end{array}$ & $100 \%$ & \multirow[t]{3}{*}{$\begin{array}{l}2 \\
8\end{array}$} & & \\
\hline & $\begin{array}{l}(2 \\
\mathrm{cm} ; 5 \mathrm{c} \\
\mathrm{m})\end{array}$ & $69 \%$ & & 5.1 & \multirow[t]{2}{*}{$\begin{array}{l}0.0 \\
8\end{array}$} \\
\hline & $\begin{array}{ll}>= & 5 \\
\mathrm{~cm} & \end{array}$ & $54 \%$ & & & \\
\hline \multirow{3}{*}{$\begin{array}{l}\text { Degree of } \\
\text { malignanc } \\
y\end{array}$} & 1 & $100 \%$ & \multirow{3}{*}{$\begin{array}{l}2 \\
8\end{array}$} & & \\
\hline & 2 & $84 \%$ & & 0.69 & 0.4 \\
\hline & 3 & $70 \%$ & & & 9 \\
\hline \multirow{2}{*}{$\begin{array}{l}\text { Chromogra } \\
\operatorname{nin} \text { A }\end{array}$} &,+++ & $87 \%$ & \multirow{2}{*}{$\begin{array}{l}2 \\
8 \\
\end{array}$} & \multirow[t]{2}{*}{1.39} & 0.1 \\
\hline & - & $50 \%$ & & & 6 \\
\hline \multirow{2}{*}{$\begin{array}{l}\text { Synaptoph } \\
\text { ysin }\end{array}$} & + & $92 \%$ & \multirow{2}{*}{$\begin{array}{l}2 \\
7\end{array}$} & \multirow[t]{2}{*}{1.85} & 0.0 \\
\hline & $\begin{array}{l}++, \\
+++\end{array}$ & $61 \%$ & & & 6 \\
\hline \multirow[t]{2}{*}{ ERc } & $\begin{array}{l}\text { None } \\
\text { or up } \\
\text { to } 10\end{array}$ & $73 \%$ & \multirow[t]{2}{*}{$\begin{array}{l}2 \\
7\end{array}$} & \multirow[t]{2}{*}{1.08} & \multirow[t]{2}{*}{$\begin{array}{l}0.2 \\
8\end{array}$} \\
\hline & $>10$ & $87 \%$ & & & \\
\hline \multirow[t]{2}{*}{ HER 2} & None & $90 \%$ & \multirow{2}{*}{$\begin{array}{l}2 \\
6\end{array}$} & \multirow[t]{2}{*}{1.99} & \multirow{2}{*}{$\begin{array}{l}0.0 \\
5\end{array}$} \\
\hline & $\begin{array}{l}\text { Presen } \\
\mathrm{t}\end{array}$ & $38 \%$ & & & \\
\hline \multirow[t]{2}{*}{ Metastasis } & None & $93 \%$ & \multirow{2}{*}{$\begin{array}{l}2 \\
8\end{array}$} & \multirow[t]{2}{*}{1.98} & \multirow{2}{*}{$\begin{array}{l}0.0 \\
5\end{array}$} \\
\hline & $\begin{array}{l}\text { Occurr } \\
\text { ed }\end{array}$ & $57 \%$ & & & \\
\hline
\end{tabular}

* p-value for the one-factor analysis of variance; $\log$ rank statistics 
Two patients who died for reasons other than cancer were excluded from the analysis of the probability of survival.

Assessing the influence of selected prognostic factors on 5-year survival it was found that the presence of metastasis $(p=0.05)$, the presence of HER $2(p=0.05)$, the level of synaptophysin $(\mathrm{p}=0.06)$ and tumour size $(\mathrm{p}=0.08)$ are statistically significant. The degree of malignancy, the occurrence of chromogranin A and ERC receptors had no significant impact on survival. The presence of HER-2 has a significant impact on the survival curves. In the presence of HER-2, the probability of 5-year survival is at a level of $38 \%$.

In assessing the total survival depending on the occurrence of metastasis, significant differences between patients with and without metastasis ( $\mathrm{p}$
$=0.06)$ was also demonstrated. The probability of 5-year survival of patients without metastasis is at $89 \%$ and is $38 \%$ higher than in the case of patients with metastasis.

The probability of 5-year survival in the group of patients with a lower $(++)$ and higher $(+++)$ concentration of synaptophysin was observed at the level of $61 \%$. This result is lower by $31 \%$ than in the case of concentration on the lowest level (+).

The assessment of survival together with the characteristics features of cancer tissue in 12 patients with distant metastatic is presented in Table 5. The probability of 5-year overall and disease-free survival was similar and amounted respectively to $78 \%$ and $60 \%$, as shown in Figure 1.

Table5. Characteristics of 12 patients who developed metastasis

\begin{tabular}{|c|c|c|c|c|c|c|c|c|c|c|c|}
\hline Age & TNM & OBS & HP & G & Rec & Her2 & CgA & Synap. & Meta & F-U & Status \\
\hline 71 & T3N1M1 & 16 & N & 2 & pos & neg & neg & + & Bones & 11 & DOD \\
\hline 73 & T1N1M1 & 12 & N & 1 & pos & neg & ++ & + & Bones & 36 & DOD* \\
\hline 66 & T2N1M1 & 12 & N & 2 & pos & pos & + & ++ & Spread & 6 & DOD \\
\hline 52 & T2N0M0 & $?$ & D & 2 & pos & neg & ++ & ++ & Brain bones & 36 & AWD \\
\hline 83 & T1N0M0 & 2 & N & 2 & neg & neg & + & + & Spread & 38 & AWD \\
\hline 53 & T1N1M0 & 10 & N & 3 & pos & neg & + & ++ & Lungs & 132 & DOD \\
\hline 47 & T3N0M0 & 12 & N & 2 & neg & neg & + & + & Brain & 28 & DOD \\
\hline 51 & T1N0M0 & 6 & D & 3 & neg & neg & + & + & Spread & 72 & AWD \\
\hline 46 & T3N1M0 & 18 & L & 2 & neg & neg & neg & + & Brain & 48 & AWD \\
\hline 55 & T1N2M0 & 12 & D & 3 & pos & pos & ++ & ++ & Liver & 39 & DOD \\
\hline 88 & T3NxM1 & 24 & D & 3 & $?$ & $?$ & neg & ++ & Liver bones & 6 & DOD \\
\hline 47 & T2N2M0 & 18 & N & 3 & pos & neg & ++ & ++ & Brain & 33 & DOD \\
\hline
\end{tabular}

OBS - tumour observation period (months), HP-microscopic diagnosis, $N-N E T, D-N E T+c a d$ uctale, L NET + ca lobulare, G -grade: G1,G2,G3. Rec - receptors: ERC/PRC; HER-2: pos. positive, neg. negative, $C g A$-chromogranin $C g A$, pos. - positive $+/++$, neg. negative, Synap -Synaptophysin positive: $+/++, n e g, F-U$ Follow up (months), DOD-death, NED no disease, AWD-alive with cancer, DOD* death not due to cancer.

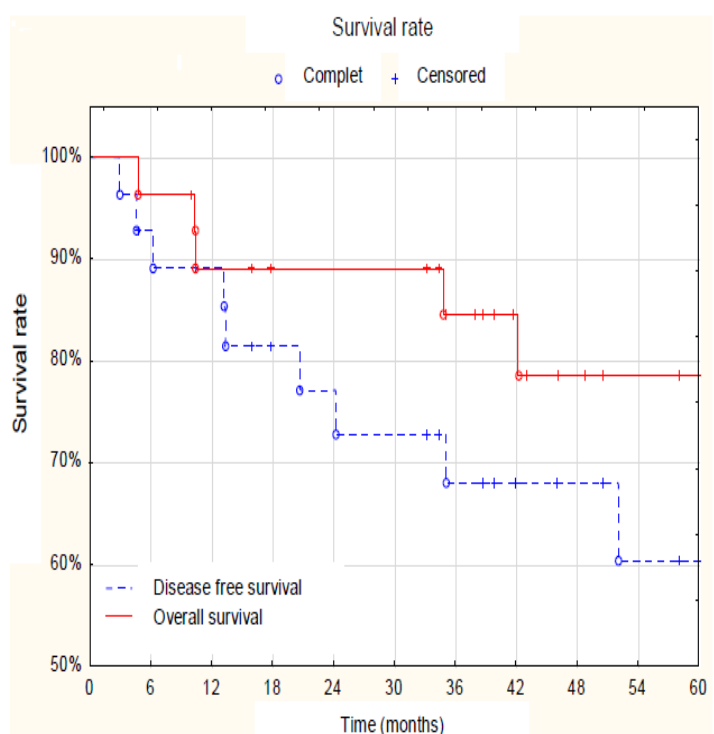

Figure1. In the study group, the probability of 5year survival in the disease-free period was $60 \%$. The probability of 5-year survival was $78 \%$

\section{DisCUSSION}

Neuroendocrine carcinoma of the breast is a rare cancer of unknown doctrine for diagnostic and therapeutic procedure and its incidence among breast cancer patients, although small (approx. $5 \%$ ), shows a continuous upward trend. Incidence of neuroendocrine cancer has been described since 1977 and only includes isolated reports. So far, the world literature describes dozens, approx. 30, of single cases from multiple centres ${ }^{[8,14-16]}$.

Most NET cases is diagnosed using palpation testing along with diagnostic imaging, ultrasound and/ or mammography [13, 16, 17]. Only minor changes were detected using MRI or radionuclide imaging methods (In-111 pentetrotide scan). This method is also used to identify not visible nodules diagnosed by other methods ${ }^{[16]}$. 
In the presented analysis of clinical features and treatment effects in 30 NET patients, the average age was 63 years, and it is consistent with other reports, because this rare cancer occurs in older women above the age of $60^{[6-8]}$.

Among the patients, the largest group consisted of patients with T1 tumours $(43 \%)$, a homogeneous neuroendocrine form(N) $48 \%$, average differentiation of cancer - G2 $(52 \%)$ with lymph node involvement (N1) $62 \%$. The domination small differentiation of cancers and spread of the disease causes that NET is seen by some authors as a tumour with worse prognosis $[9,18]$.However, exactly the opposite opinions are currently present ${ }^{[4,13]}$.

According to the WHO classification, diagnosis of neuroendocrine tumour is associated with a diagnosis of at least one marker - chromogranin and/or synaptophysin. The assessment of survival and the occurrence of metastasis depending on the discovered chromogranin and/or synaptophysin markers in the analysed samples showed that the expression of both markers is a positive prognostic associated with a higher proportion of 3-year survival of $65 \%$ vs $43 \%$ with only a single marker present. At the same time, it was found that the high content of synaptophysin reduces the probability of 5-year survival. Similar correlation was not observed in the case of $\mathrm{CgA}$.

In contrast, the lack of HER-2 receptor in the NET cancer tissue caused that the probability of 60-month survival was significantly higher, amounting to $81 \%$ compared to $38 \%$ with the receptor present.

Among all 30 patients, ERC and PRC receptors were found in respectively $81 \%$ and $61 \%$ of patients. HER-2 receptor occurred in only $10 \%$. The presence of ERC and PRC receptors in our analysis was associated with a better prognosis and their absence was associated with a higher incidence of metastasis. A similar observation of a favourable impact of receptors on the prognosis was observed by other authors, which is why they emphasise the important role of hormonal therapy in the treatment of NET ${ }^{[8,9}$, ${ }^{18]}$.

In 12 out of $30(40 \%)$ patients, distant metastasis occurred from 6 months to 11 years after NET treatment. Among these patients, 4 (33\%) were triple receptor-negative. Assessing the impact of cancer cases among relatives, it seems that this features cannot be classified as a negative prognostic factor.

Treatment of patients with NET was conducted according to the degree of clinical progression in accordance with the guidelines of the National Comprehensive Cancer Network $(\mathrm{NCCN})$ for ductal or lobular breast cancer. After the surgery, radiotherapy and chemotherapy was used in advanced cases, and hormonal therapy and Herceptin in case of positive receptors. The presence of receptors in the NET cancer tissue was an indication for hormone therapy, which is recommended by other authors in this type of cancer ${ }^{[15,18]}$.

Currently, a tendency can be observed in the literature to abandon radiotherapy, whereas chemotherapy and hormonal therapy are considered relevant and effective methods. Early diagnosis of the disease, which reduces treatment only to surgical excision of the tumour, is also emphasised. The rarity of cases results in a lack of a unified treatment doctrine for patients with NET [8,19-24].

The analysis is carried out on a group of 30 patients and the preliminary observations obtained may contribute to the knowledge of the course and dynamics of NET breast cancer. However, the presented results need to be confirmed by other authors. Lack of randomised trials does not allow for unambiguous assessment of prognosis and selection of the best treatment for NET. Currently, neuroendocrine carcinomas are seen by some authors as tumours with a milder course and a good prognosis and by others as tumours with a bad prognosis with a very aggressive course [5,8,18,25-28].

\section{Conclusions}

1. Neuroendocrine carcinoma of the breast is a rare cancer of unknown doctrine for diagnostic and therapeutic procedure and its incidence among breast cancer patients, although small (approx. 5\%), shows a continuous upward trend.

2. Assessing the influence of selected prognostic factors on 5-year survival it was found that the presence of metastasis, the presence of HER 2, the level of synaptophysin and tumour size are statistically significant.

3. The presence of HER-2 has a significant impact on the survival curves. 
4. The assessment of survival and the occurrence of metastasis depending on the discovered chromogranin and/or synaptophysin markers in the analysed samples showed that the expression of both markers is a positive prognostic with a higher proportion of 3-year survival.

\section{REFERENCES}

[1] National Cancer Data Base, Department of Epidemiology and Cancer Prevention, Onco logy Centre - Institute of Warsaw; reports based on data from the Oncology Centre in 20022010.www.onkologia.org.pl.(20.07.2017).

[2] Winchester DJ. Winchester DP. Atlas of Clinical Oncology - Breast Cancer. B.C. Decker Inc., London 2000.

[3] Massironi S, Sciola V, Peracchi M, Ciafardini C, Spampatti MP, Conte D. Neuroendocrine tumors of the gastro-enteropancreatic system. World J Gastroenterol 2008; 21:14(35):53775384.

[4] Jeziorski A. Breast Cancer [ed] Kordek R. Oncology. Via Medica. 2007;202-232.

[5] Tempska-Esden Z, Lewczuk A, Majda W, et al. Primary neuroendocrine carcinoma of the breast - case study. Endokrynol Pol, 2010;61(2):246-247.

[6] Ehrenstein CR, Arndt J, Bucendahl AC, et al. Solid neuroendocrine carcinomas of the breast metastases or promary tumors? Breast Cancer Res Treat 2010; 124(2):413-417.

[7] Tavassoli FA, Devilee P. World Health Organization classification of tumors. Pathology and genetics organs, IARC, Lyon 2003; 9-112.

[8] Adegbola T, Conelly CE, Mortimer G. Small cell neuroendocrine carcinoma of the breast: a report of three cases and review of literature. $J$ Clin Pathol 2005;58(7):775-778.

[9] Noccioli P, Grossi S, Tavoletta S, Scognamiglio MT, Natoli C, Cianchetti E et al. Neuroendocrine tumors of the breast: our experience." Clinica Oncologica PO "G. Bernabeo," Dipartimento di Neuroscienze, Chieti, Italy.

[10] Ellis IO, Schinitt SJ, Sastre-Garau X, et al. Tumours of the breast, neuroendocrine tumours. In: Tavassoli F. A., Devilee P. editors. World Health Organization classification of tumours:pathology and genetics of tumours of the breast and female genital organs. Lyon (France): International Agency for Research on cancer (IARC) 2003;32-34.

[11] Papotti M., Macri L., Finzi G., Capella C., Eusebi V., Bussolanti G. Neuroendocrine differentiation in carcinomas of the breast: a study of 51 cases. Semin Diagn Pathol 1989;6(2):174-188.

[12] Kaltsas GA, Besser GM, Grossman AB. The diagnosis and medical management of neuroendocrine tumours. Endocr Rev 2004; 25(3):458-511.

[13] Caplin M.E., Widenmann B.. The management of patients with neuroendo-crine tumours. Endocrine-Realated Cancer. 2000,80, (suppl.1), 425-26.

[14] Navrozoglou I, Vrekoussis T, Zervoudis S et al. Primary atypical of the brast: A case report and brief overview of evidence. World J Surg Oncol 2011; 18:9:52.

[15] Nicoletti S, Papi M, Drudi F, et al. Small cell neuroendocrine tumor of the breast in a 40 year-old woman: a case report. J Med Case Rep 2010;30:4:201

[16] Panareo S, Carcoforo P, Lanzara S, et al. Radiolabelled somatostatin analoges for diagnosisi and radio-guided surgery of neuroendocrine breast cancer undetectable with conventional omaging procedures. Breast 2008; 17(1):111-114.

[17] Ćwikła JB, Sankowski AJ, Furmanek MI, et al. Diagnostic radiology of neuroendocrine tumours (CT, MRI, ultrasound). Probl Med Nuklearnej 2007; 21(41,42):19-25.

[18] Jochems L, Tjalma WA. Primary small cell neuroendocrine tumour of the breast. Eur $J$ Obstet Gynecol Reprod Biol 2004; 10: 115(2):231-223.

[19] Wei B, Ding T, Xing Y, et al. Invasive carcinoma of the breast a distinctive subtype of aggressive mammary carcinoma. Cancer 2010;1;116(19):4463-4473.

[20] Upalakalin JN, Collins LC, Tawa N, Parangi S. Carcinoid tumors in the breast. Am J Surg 2006; 191(6):799-805.

[21] Hartgrink HH, Lagaay MB, Spaander PJ, Mulder H, Breslau PJ. A series of carcinoid tumours of the breast. Eur J Surg Oncol 1995; 21(6):609-612.

[22] Jablon LK, Somers RG, Kim PY. Carcinoid tumor of the breast treatment with breast conservation in three patients. Ann Surg Oncol 1998; 5(3):261-264.

[23] Modlin I. M., Shapiro M. D., Kidd M. An analysis of rare carcinoid tumors: clarifying these clinical conundrums. World J Surg 2005; 29(1):92-101.

[24] Lu CS, Huang SH, Ho CL, Chen JH, Chao TY. Primary neuroendocrine carcinoma of the breast. J BUON 2014;19(2):419-429. 
[25] Berruti A, Saini A, Leonardo E, Cappia S, Borasio P, Dogliotti L. Management of neuroendocrine differentiated breast carcinoma. Breast 2004; 13(6):527-529.

[26] Nicoletti S., Papi M, Drud F, et al. Small cell neuroendocrine tumor of the breast in a 40 year-old woman: a case report. J Med Case Rep 2010; 30:4:201.
[27] Sapino A, Righi L, Cassoni P, Papotti M, Pietribiasi F, Bussolati G. Expression of the neuroendocrine phenotype in carcinomas of the breast. Semin Diagn Pathol 2000; 17(2):127137.

[28] Shin SJ, DeLellis RA, Ying L, Rosen PP. Small cell carcinoma of the breast: a clinico pathologic and immuno histochemical study of nine patients. Am J Surg Pathol 2000; 24(9):1231-1238.

Citation: Barbara Kozakiewicz, Małgorzata Czetwertyńska, Małgorzata Chądzyńska. Neuroendocrine Carcinoma of the Breast - Preliminary Analysis of Treatment Results of 30 Patients. ARC Journal of Gynecology and Obstetrics. 2017; 2(1):7-14. doi:dx.doi.org/10.20431/2456-0561.0201003.

Copyright: (C) 2017 Authors. This is an open-access article distributed under the terms of the Creative Commons Attribution License, which permits unrestricted use, distribution, and reproduction in any medium, provided the original author and source are credited. 